\title{
Debate
}

\section{Power Resources and Global Capitalism}

\author{
Stefan Schmalz, Friedrich Schiller University, Germany \\ Carmen Ludwig, University of the Witwatersrand, South Africa \\ Edward Webster, University of the Witwaterstand, South Africa
}

\begin{abstract}
[Editor's Note: This piece is in response to an ongoing debate on the Power Resources Approach, which first appeared in a Special Issue of the Global Labour Journal (Volume 9, Issue 2) in May 2018. In that issue there were comments by Andreas Bieler, Akua O. Britwum and Marissa Brookes. See also the Debate section in Volume 9, Issue 3 (September 2018), where there were debate pieces by Alexander Gallas and Jörg Nowak. This response has been written by the guest editors of the Special Issue.]
\end{abstract}

We welcome the five responses to our introductory article published in the May and September 2018 issues of the Global Labour Journal and thank the editors of the GLJ for providing a platform for a more in-depth discussion of the origins, development and application of the Power Resources Approach (PRA). Our aim is to deepen the debate among critical labour scholars by introducing into the dominant narrative of union decline worldwide examples of innovative trade unionism. PRA is a way of analysing these developments, and we look forward to many more contributions on this, and other ways, of exploring the future of labour.

Clearly there are important areas of agreement between ourselves and the comments made on our article. There are also areas where we feel our approach to PRA has been misunderstood, and there are areas of disagreement. Let us deal with the agreements first.

\section{Areas of Agreement: An Emerging Consensus}

Firstly, as Andreas Bieler (2018) acknowledges, the PRA approach does not see workers simply as passive victims of forces beyond their control but emphasises instead the possibility of worker agency. While neo-liberal globalisation has closed down some options for union organisation, it has also opened up new opportunities for trade union innovation (Fichter et al., 2018). As the articles in the Special Edition on Acquiring and Applying Power Resources demonstrate, new forms of organisation are emerging as workers identify and conceptualise new sources of power. Akua Britwum (2018) notes how the use of the PRA in the informal economy has expanded our understanding of the deployment of power resources to include societal power to compensate for limitations in structural and associational power.

Secondly as Marissa Brookes (2018) suggests, the PRA helps shift the debate from a focus on the impact of globalisation on labour to the strategic choices being exercised by the labour movement. Brookes emphasises the practical utility of the PRA as a way in which labour leaders can begin a process of renewal. She usefully clarifies the notion of associational power by defining it as the capacity of workers to mobilise in order to act collectively. We draw on the article by Alpkan Birelma (2018) in the Special Issue to highlight the importance of subjectivities, 
in particular the orientation of worker leaders, in mobilising associational power in a small transport union in Turkey.

Thirdly, and most importantly, we agree with Alexander Gallas (2018) that the PRA is not a universal formula and has to be situated in an analysis of the relationship between capital and labour. It is a tool that can be utilised to understand and build worker organisation. But, as we emphasise in our article, context matters (Schmalz, Ludwig and Webster, 2018). We reproduce several articles in the Special Edition from the Global South and North which illustrate the importance of social context and the relationship between capital and labour in applying the PRA. The articles by Arbind Singh and Sachin Kumar (2018) on street vendors in India and Dave Spooner and John Mark Mwanika (2018) on the Amalgamated Transport and General Workers' Union of Uganda (ATGWU) both show strategies of building a hybrid organisation that has assisted the unions in bridging the divide between formal and informal workers. This has united different fractions of the working class, achieving substantial gains for informal workers and reducing their vulnerability. Sarah Hinz (2018) shows in her article on alternative trade unions in Russia how the rise of transnational automotive companies led to the formation of a new working class, thereby discussing the limits of bottom-up processes of unionisation under authoritarian rule.

\section{Areas of Misunderstanding: Contextualising the PRA}

The issue of class relations leads us to an important misunderstanding of the PRA by some of the responses. In particular Gallas (2018) and Nowak (2018) perceive the PRA as a self-referential research heuristic that is largely detached from an analysis of global capitalism. At this point, it is important to clarify the intention of the PRA and to outline some of the discussions that took place a decade ago on the development of this approach. The main intention of the PRA was twofold: Firstly, it is a tool designed to analyse spaces of action beyond established routines of trade union action, thus focusing on innovative forms of unionism. The notion of four power resources (structural, associational, institutional and societal power) allows unions to analyse possible options for actions beyond seemingly path-dependent patterns of action such as a onesided reliance on institutional power. Our approach is not inspired by a rational-choice logic, as Nowak argues. Our intention is to provide unions with an opportunity to reflect on strategic goals, thereby assisting them in making a strategic choice. Trade unions are heterogeneous actors, and questions of strategy are usually contested within unions as these discussions imply different forms of actions and types of unionism.

Secondly, the PRA is not blind to the structuring conditions of capitalism as Bieler and others indicate. It is rather designed to bring capitalism back into the analysis of trade unions. The notion of structural power - marketplace bargaining power and workplace bargaining power - should be understood as an entry point to reflect upon the impact of global capitalism on labour power, such as through the emergence of new production regimes (e.g. Taylorist assembly-line work) or the transnationalisation of capital (e.g. the threat of capital relocation) (Silver, 2003: 47ff.). Consequently, we are not claiming that the approach is a theory of capitalism. It is rather an intermediate concept that focuses on labour relations and actions and thus the level between structural developments and agency. There are a number of studies linking the PRA to theories of capitalism or an analysis of workers' subjectivities, showing how to connect these different levels of analysis (Webster, Lambert and Bezuidenhout, 2008; Schmalz and Weinmann, 2016; Becker, Kutlu and Schmalz, 2017; Lehndorff et al. 2017; Birelma, 2018; Munck, 2018). 
It is important to emphasise that the PRA acknowledges both structure and worker agency. As indicated, one of the aims of the PRA is to highlight the possibility of worker agency at a time when the dominant narrative continues to be that of trade union decline in the face of globalisation processes. The PRA challenges the assumption that there is no alternative by arguing that worker agency can make a difference. Arguably, in its concern to correct the onesidedness of a pendulum that sometimes over-emphasises structure, the PRA may at times have swung the pendulum too far in the opposite direction.

The two points mentioned above can be elaborated by referring to the case of Germany, a case both Nowak and Gallas make mention of in their articles. In Germany, the PRA was introduced about a decade ago in order to take into account far-reaching changes in labour relations (Brinkmann et al., 2008: 19ff.). For a long time, German unions had relied on their institutional power in the dual system of industrial relations (works councils and collective agreements). However, since the 1990s decreasing associational power (shrinking membership numbers and a growing representation gap) and structural changes in the economy (rising unemployment, plant relocations and a shareholder value orientation) had weakened institutional power through developments such as the shrinking coverage rate of collective agreements and, consequently, had led to stark changes of the institutions' mode of operation. For instance, even traditional union strongholds in automobile factories were facing a growing portion of precarious agency workers who were not legally represented by works councils. In other words, far-reaching trends such as privatisation, financialisation and globalisation had altered the structure of German capitalism, leading to a (re)commodification of public goods and social security provisions and a fragmentation of labour relations. The PRA was brought in by scholars and unionists in order to challenge established routines of action, arguing that in this changing context unions have to rely on building associational power by focusing on organising and campaigning, instead of relying on their shrinking institutional power (Brinkmann et al., 2008: 71ff.; Schmalz and Thiel, 2017).

It is particularly striking that Nowak (2018) and Gallas (2018) both refer in their articles to labour conflicts in former German state-owned companies and state-dominated or highly regulated economic sectors (airlines and railways) in order to criticise the PRA without contextualising the cases in the larger development of German capitalism, thereby drawing a distorted picture of the role of unions in these developments. For instance, in the case of recent labour conflicts in the railway sector, marketisation has played a major role, both changing working conditions and eroding institutional power, a process German rail unions EVG and its predecessors GDA and Transnet did not vigorously challenge as they relied on a strategy of social partnership without reflecting upon the changing context.

Indeed, the PRA played an important role in a recent dispute in the low-cost, Irish airline Ryanair, one of the largest and fastest-growing airlines in Europe. Union organisers and scholars made use of the PRA to analyse the balance of forces in Ryanair and to explore how latently available power resources could be strategically used in the context of an organising campaign (for details see Butollo, 2019). While Ryanair circumvented national labour laws by providing pilots and cabin crew members with Irish employment contracts, the public/private service sector union in Germany, ver.di, was unable to draw on its institutional power to improve working conditions. Innovative organising strategies, changing economic conditions and the growing marketplace bargaining power of cabin crew members, enhanced a process where the union was able to organise a precariously employed, internationally composed workforce with very high fluctuation in a decidedly anti-union company. As a result of strikes that included pilots and cabin crew members, a transnational union campaign (\#CabinCrewUnited), and coordinated collective action in several European countries, Ryanair was forced to recognise unions as 
negotiating partners in 2017 and to conclude the first bargaining agreement with ver.di. However, the PRA is not a tool meant to celebrate or declare every outcome of union action a success. On the contrary, its strength in campaigns like those in Ryanair lies in providing a nuanced picture of the ambivalent expressions of power resources, and thereby pointing to possibilities and potential pitfalls of union actions.

Another area of misunderstanding is on the role of institutional power. Gallas and Nowak seem to assume that we regard institutional power as an inherently positive power resource. However, in our introduction to the Special Issue, we describe institutional power as a doubleedged sword. While it can guarantee trade unions' rights such as freedom of association, participation in labour-market and conflict-resolution institutions on the one hand, it also restricts unions' capacity, creating a frame that constrains trade union strategies and actions (Schmalz, Ludwig and Webster, 2018). Therefore, institutional power is dependent on context, history and political tradition. It has a different role and meaning in each country, in the Global South and North. As we outline in our introductory article, in South Africa the institutionalisation of labour relations, which implies the acceptance of the underlying social order by all parties, has remained partial and highly contested (see also Von Holdt, 2010). Furthermore, as institutional arrangements and practices are the outcome of concrete struggles and negotiations of labour movements, they cannot easily be transferred from one context to another (Webster, 2014). Accordingly, attempts to introduce the German model of codetermination in South Africa have unsurprisingly failed (Webster, Masondo and Bischoff, 2019).

\section{Areas of Disagreement: The Nature of Unions}

This leads us to a major point of disagreement that is related to the very nature of unions in capitalist societies. While discussing our approach to the PRA, Gallas (2018) uses the concept of intermediary institution as an alternative concept to power resource oscillating between being class organisations and organisations of mass integration between capital and labour. Nowak (2018) does not put forward a clear theoretical foundation for the class unionism he is arguing for, but is critical of unions as legitimate organisations of interest representation, seeing them as organisations that are inevitably integrated into corporate structures. This places Nowak very much in what Richard Hyman (1971: 11-25) called, many years ago, the pessimistic interpretation of trade unionism. ${ }^{1}$ Accordingly, from his perspective, union revitalisation is only a "metaphor for awakening of a dead body that should serve as a warning sign towards the zombie nature of reanimated social democracy".

Let us first turn to Gallas' argument. The concept of intermediary organisation was originally introduced by a group of critical scholars in Frankfurt (Esser, Jacobi, Müller-Jentsch, etc.) in the 1970s in order to criticise tendencies of bureaucratisation and selective interest representation of German trade unions. However, later it turned into a structurally conservative concept as

\footnotetext{
${ }^{1}$ There has been a long-standing debate among scholars and activists on the nature and role of trade unions since their origins in nineteenth-century Europe. The debate is between those who believe that labour's role in social change is inherently limited and those who believe labour has the potential to play a central role in the transformation of society (Webster, 2013). In the pessimistic tradition, trade unions do not facilitate, and may in fact inhibit, the revolutionary transformation of capitalist society (Hyman, 1971). The other position, which Hyman calls the optimistic tradition, perceives a significant revolutionary potential in trade union activity and gives the union a much more central role in transformation. In our understanding, trade unions are not limited to a particular, social-democratic agenda but can play a transformative societal role, as they are also political actors that have the capacity to shape society.
} 
scholars such as Müller-Jentsch (1995) began to argue that the German model with unions as intermediate organisations was a highly innovative model, as German unions did not only do comparatively well in influencing state politics, but also managed to continue to be capable of acting despite emerging neo-liberalism in the 1980s and 1990s. During this time, the concept of intermediary institutions was hegemonic in scholarly discussions on trade unions in Germany. However, since the late 1990s, the concept has been heavily criticised by leftist scholars as being historically outdated as it referred to a type of unionism that was present at the height of Fordism, while modern unions were facing increasing pressure and representation gaps and, more generally, were no longer able to take on the function of organising state politics (Beerhorst, 2005; Dörre, 2005). The concept was also perceived as supporting established routines of action. At this point, the PRA was introduced in order to open up new horizons in scholarship and trade union politics.

For the same reason, Nowak's argument that the PRA supports a social-democratic and corporatist model of trade unions developed in post-war Western Europe seems questionable. ${ }^{2}$ Our approach to the PRA tends rather to highlight the primary sources of workers' power (structural power), based on the ability to wage conflicts and the vitality of labour organisations (associational power) and its possibilities of cooperation with social movements (societal power), while taking into account institutional configurations (institutional power).

As already mentioned, the PRA is not a concept designed to grasp the structural logic of capitalism, but rather a tool to explain how workers empower themselves in order to confront capital and the capitalist state in concrete cases. This might be a rather modest agenda, but it is a necessary first step in rebuilding the power of labour. In this sense, the PRA is best understood as a tool of analysis to strengthen organisation and to contribute to the rebuilding of the labour movement.

In the case of the transport union Tümtis in Turkey, the socialist orientation of trade union leaders made a difference in the choice of strategies and the development of the union's power resources, as Alpkan Birelma (2018) demonstrates. While it is true that the PRA does not aim to provide a universal model of how to achieve socialism or to prescribe political goals to be achieved by labour movements, socialist goals are entirely in line with the approach. However, it is up to workers' organisations to define their goals and strategies depending on the specific context, and their historical and political traditions. Due to its organic link to trade union practices and struggles, the PRA is a tool for learning from these experiences and for critical reflection and engagement with trade unions.

\section{Conclusion: An Evolving Research Agenda}

We concluded our original article by suggesting that there are forms of violent labour protests, which do not directly relate to the sources of labour power usually discussed in the power resources approach. The institutionalisation of industrial conflict is increasingly being eroded, not only in the Global South but also in the North, and the labour market is fragmenting along new fault lines.

\footnotetext{
${ }^{2}$ Besides the fact, that Korpi (1983) is referring to power resources in the context of the European welfare state, it is a misconception to link the central roots of the PRA to Korpi's concept. The current debate on labour power was strongly influenced by Beverly Silver (2003). Taking Wright's (2000) distinction between associational and structural power as a point of departure, she introduced the concept of workplace and marketplace bargaining power in her study on the recurring rise and decline of labour movements worldwide.
} 
There are also new movements and forms of organisation emerging alongside the decline of traditional unions. Organisations of informal workers often differ from traditional unionism in their structures and strategies. Where trade unions have taken up the issues of informal workers, unions have also undergone fundamental changes. They often become "hybrid" organisations, which include different forms of organisations and blur the distinction between traditional unionism, informal workers' associations or cooperatives (Gadgil and Samson, 2017; Fichter et al., 2018: 5f).

These are some of the challenges, and there are many others, that face the power resources approach if it is to become a useful tool of analysis in the age of global capitalism. The time has arrived to expand the research agenda in order to explore the use of labours' power beyond fixed institutional settings and beyond traditional models of unionism in the North, but particularly in the many precarious societies of the Global South.

\section{REFERENCES}

Becker, K., Y. Kutlu and S. Schmalz (2017) Kollektive Machtressourcen im Care-Bereich: Die mobilisierende Rolle des Berufsethos. In Streiks in den sozialen Dienstleistungen, edited by I. Artus, P. Birke, S. Kerber-Clasen and W. Menz. Hamburg: VSA.

Beerhorst, J. (2005) Kritik der Intermediaritätsthese. Industrielle Beqiehungen, 12(2): 178-188.

Bieler A. (2018) Agency and the Power Resources Approach: Asserting the Importance of the Structuring Conditions of the Capitalist Social Relations of Production. Global Labour Joumal, 9(2): 243-248.

Birelma, A. (2018) When Local Class Unionism meets International Solidarity: A Case of Union Revitalisation in Turkey. Global Labour Journal, 9(2): 215-230.

Brinkmann, U., H-L. Choi, R. Detje, K. Dörre, H. Holst, S. Karakayali and C. Schmalstieg (2008) Strategic Unionism: Aus der Krise zur Erneuerung? Umrisse eines Forschungsprogramms.

Britwum, A.O. (2018) Power Resources and Organising Informal Economy Workers. Global Labour Journal, 9(2): 249-253.

Brookes, M. (2018) Power Resources in Theory and Practice: Where to Go from Here? Global Labour Journal, 9(2): 254-257.

Butollo, F. (2019, forthcoming) Die Hölle friert zu. Machtressourcen und Organizing bei Ryanair. In Entgrenz̨te Arbeit, (un)begrenzte Solidarität? Bedingungen und Strategien gewerkschaftlichen Handelns im flexiblen Kapitalismus, edited by C. Ludwig, H. Simon and A. Wagner. Münster: Westfälisches Dampfboot.

Dörre, K. (2005) Intermediarität und gewerkschaftliche Identität. Industrielle Bezৃiehungen, 12(2): 207-212.

Fichter, M., C. Ludwig, S. Schmalz, B. Schulz and H. Steinfeldt (2018) The Transformation of Organised Labour. Mobilising Power Resources to Confront 21st Century Capitalism. Berlin: FES.

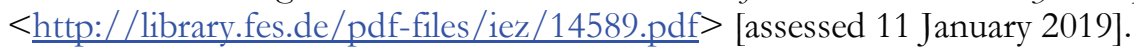

Gadgil, M. and M. Samson (2017) Hybrid Organisations, Complex Politics: When Unions Form Cooperatives. In Crossing the Divide: Precarious Work and the Future of Labour, edited by E. Webster, A.O. Britwum and S. Bhowmik. Pietermaritzburg: University of KwaZulu-Natal Press.

Gallas, A. (2018) Class Power and Union Capacities: A Research Note on the Power Resources Approach. Global Labour Journal, 9(3): 348-352.

Hinz, S. (2018) The Ambivalence of Structural Power: Alternative Trade Unions Challenging Transnational Automotive Companies in Russia. Global Labour Journal, 9(2): 167-181.

Hyman, R. (1971) Marxism and the Sociology of Trade Unionism. London: Pluto Press.

Korpi, W. (1983) The Democratic Class Struggle. New York: Routledge. 
Lehndorff, S., H. Dribbusch and T. Schulten (2017) Rough Waters. European Trade Unions in a Time of Crises. Brussels: ETUI.

Müller-Jentsch, W. (1995) Auf dem Prüfstand. Das deutsche Modell industrieller Beziehungen. Industrielle Beriebungen, 3(1): 11-24.

Munck, R. (2018) Retbinking Global Labour. Towards a New Social Settlement. Newcastle upon Tyne: Agenda Publishing.

Nowak, J. (2018) The Spectre of Social Democracy: A Symptomatic Reading of the Power Resources Approach. Global Labour Journal, 9(3): 353-360.

Schmalz, S., C. Ludwig and E. Webster (2018) The Power Resources Approach: Developments and Challenges. Global Labour Journal, 9(2): 113-134.

Schmalz, S. and M. Thiel (2017) IG Metall's Comeback: Trade Union Renewal in Times of Crisis. Journal of Industrial Relations, 39(4): 465-486.

Schmalz, S. and N. Weinmann (2016) Between Power and Powerlessness: Labor Unrest in Western Europe in Times of Crisis. Perspectives on Global Development and Technology, 15(5): 543-566.

Silver, B.J. (2003) Forces of Labor. Workers' Movements and Globalization since 1870. Cambridge: Cambridge University Press.

Singh, A. and S. Kumar (2018) Securing, Leveraging and Sustaining Power for Street Vendors in India. Global Labour Journal, 9(2): 135-149.

Spooner, D. and J.M. Mwanika (2018) Transforming Transport Unions through Mass Organisation of Informal Workers: A Case Study of the ATGWU in Uganda. Global Labour Journal, 9(2): 150-166.

Von Holdt, K. (2010) Institutionalisation, Strike Violence and Local Moral Orders. Transformation: Critical Perspectives on Southern Africa, 72/73: 127-151.

Webster, E. (2013) Sword of Justice or Defender of Vested Interest? South African Labour in Comparative Perspective. Retbinking Development and Inequality, 2 (Special Issue): S.97-108.

Webster, E. (2014) The Promise and the Possibility: South Africa's Contested Industrial Relations Path. Transformation: Critical Perspectives in Southern Africa, 81/82: 208-235.

Webster, E., R. Lambert and A. Bezuidenhout (2008) Grounding Globalisation: Labour in the Age of Insecurity, Oxford: Blackwell.

Webster, E., T. Masondo and C. Bischoff (2019) Workers' Participation at Plant Level: The South African Case. In The Palgrave Handbook of Workers' Participation at the Plant Level, edited by S. Berger, L. Pries and M. Wannöffel. Basingstoke and New York: Palgrave Macmillan.

Wright, E.O. (2000) Working-class Power, Capitalist-class Interests and Class Compromise. American Journal of Sociology, 105(4): 957-1002.

\section{BIOGRAPHICAL NOTES}

STEFAN SCHMALZ is a senior lecturer at the Institute of Sociology, Friedrich Schiller University in Jena, Germany. [Email: s.schmalz@uni-jena.de]

CARMEN LUDWIG is a postdoctoral researcher at Giessen University and currently a visiting researcher at the Society, Work and Development Institute (SWOP) at the University of the Witwatersrand. Her work is supported by a postdoctoral fellowship of the German Academic Exchange Service (DAAD). [Email: Carmen.Ludwig@sowi.uni-giessen.de]

EDWARD WEBSTER is a professor emeritus in the Society, Work and Development Institute (SWOP) at the University of Witwatersrand where he leads the Decent Work and Development Initiative. He is also the Interim Director of the recently launched Southern Centre for Inequality Studies (SCIS). [Email: Edward.Webster@wits.ac.za] 